\title{
ГОСТРА ПРОМЕНЕВА ХВОРОБА: ВНЕСОК УКРАЇНСЬКИХ ВЧЕНИХ (повідомлення перше)
}

Інститут фбізіології імені О.О. Богомольця НАН України - лідер з вивчення проблем гострої променевої хвороби. Наукові школи О.О.Городецького, Є.Ю.Чеботарьова. Німецький біофізик українського походження Б.М.Раєвський та професор Є.Б. Закржевський

\author{
М.П. Бойчак
}

Украӥнська військово-медична академія, м. Київ, Україна

Мета. Розглянути внесок українських вчених у розвиток уявлень щодо біологічної дії іонізуючого випромінювання, патогенезу, клініки, діагностики, лікування та профілактики гострої променевої хвороби.

Матеріали та методи. У дослідженні використано історичний і бібліосемантичний методи з метою повного розкриття питань становлення та розвитку радіаційної медицини, зокрема актуальних питань гострої променевої хвороби.

Результати. Розглянуто основні досліжження украӥнських вчених Інституту фізіології імені О.О.Богомольця АН УРСР та окремих дослідників - украӥнців за походженням (Б.М. Раєвський та Є.Б. Закржевський) з питань медичної радіології, участь їх у формуванні нинішніх уявлень щодо гострої променевої хвороби. Показано їх роль у вивченні питань патогенезу, клінічного перебігу, лікування та профілактики гострої променевої хвороби. Виявлені пріоритетні напрями досягнень, що вплинули на позитивні результати лікування гострої променевої хвороби у ліквідаторів аварії на Чорнобильській АЕС.

Висновки. Українськими вченими Інституту фізіології імені О.О. Богомольця АН УРСР та окремими дослідниками - українцями за походженням (Б.М. Раєвський, Є.Б. Закржевський) розроблені важливі наукові напрями з вивчення гострої променевої хвороби (зроблено певний внесок у вивчення патогенетичних механізмів захворювання, детально описано розгорнуту картину основних клінічних синдромів; обгрунтовано принцип комплексного, патогенетичного лікування гострої променевої хвороби; винайдено, вивчено та застосовано низку ефективних протипроменевих засобів, різних механізмів дії, що мають як радіозахисні властивості, так і знижують ступінь променевого ураження організму ), які отримали визнання і практичне застосування при лікуванні постраждалих під час аварії на Чорнобильській АEC. Завдяки досягненням українських вчених були сформовані сучасні уявлення про гостру променеву хворобу.

Ключові слова: гостра променева хвороба, радіобіологія, медична радіологія, іонізуюче випромінювання, рентгенівське опромінення, гама-опромінення, нейтронне опромінення, радіопротектори.

Вступ. За доволі короткий історичний період з питань гострої променевої хвороби (ГПХ) у світі написано багато наукових i популярних статей, монографій, керівництв. На жаль, ми не знайшли праць, у яких систематизовано висвітлювався б внесок українських вчених у цю складну медикобіологічну проблему.

Біологічна дія іонізуючого випромінювання була предметом вивчення 3 перших років відкриття рентгенівських променів і радіоактивності. Це сталося 13 лютого 1896 року, коли українець Іван Пулюй (професор вищої технічної школи у Празі) провів фундаментальні дослідження природи і властивостей щойно відкритих Х-променів, результати яких опублікував у двох статтях «Доповідей Віденської академії наук». А незадовго перед цим, у січні цього ж року, Пулюй зробив і опублікував кілька якісних знімків, які згодом стали називатись рентгенівськими, зроблених за допомогою його «катодної лямпи». Щоправда, не Пулюю приписали це відкриття, а німецькому вченому В.К.Рентгену, який незадовго перед цим, 28 грудня 1895 року, опублікував повідомлення «Про новий тип променів», у якому, власне, i йшлося про Xвипромінювання. Однак за 14 років перед тим уже існувала «лампа Пулюя», що випромінювала такі промені.

Відкриття природної радіоактивності (А. Беккерель, М. Складовська-Кюрі, П. Кюрі), відкриття атомних ядер 3 можливістю ї трансформації в ядра інших хімічних елементів і вивільненням при цьому величезної (атомної) енергії (Е. Резерфорд), штучної радіоактивності (Ірен і Фредерік Жоліо-Кюрі), штучного розпаду (поділу) ядер урану (О. Ган і Ф. Штрасман) дало зрозуміти, що людство отримало новий фактор можливість додаткового опромінення, яке за 
своєю інтенсивністю перевищує природне опромінення і характеризується великим діапазоном доз, від незначних і до великих, що призводять до загибелі організму.

Tе, що рентгенівські промені та іонізуюча радіація викликають в організмі певні фізіологічні і патологічні зміни, було зрозуміло вже на прикладі іï перших дослідників. Жертвами радіації стали помічник К. Рентгена В. Груббе, першовідкривачі природної радіоактивності А.Беккерель і М. Складовська-Кюрі, штучної радіоактивності - Ірен Жоліо-Кюрі, один із піонерів променевої терапії раку австрійський рентгенолог Г. Гольцкнехт. До 1907 р. було вже відомо, як мінімум, щодо семи смертей від іонізуючої радіації, а загальна кількість лікарів-рентгенологів, які померли від опромінення за перші два десятиріччя ії використання досягла сотень [1]. Перші променеві ушкодження із загальними та місцевими проявами описувалися також у хворих, яким проводилось іонізуюче випромінювання з лікувальною метою.

Від променевої хвороби постраждав і Сергій Петрович Григор'єв (1878-1920), якому судилося стати засновником 20.07.1920 першого в Україні державного наукового рентгенологічного закладу - Всеукраїнської рентгенівської академії, з 1923 р. - Рентгеноонкологічний інститут (сьогодні - Інститут медичної радіології імені С.П. Григор`єва НАМН України). Його ім'я значиться на меморіалі в Гамбурзі (серед 169 прізвищ), установленому у 1936 p. і присвяченому «рентгенологам і радіологам усіх націй, які пожертвували своїм життям у боротьбі проти хвороб ближніх» [2].

У ті роки (до застосування у $1945 \mathrm{p}$. атомного бомбардування Хіросіми і Нагасакі) такого поняття як «гостра променева хвороба» (ГПХ) не існувало. Мова йшла про променеві ураження окремих ділянок тіла чи загального ураження, навіть 3 летальними наслідками, але чіткого уявлення щодо зв'язку всього різноманіття біологічних ефектів 3 дозою опромінення ще не було; не було єдиної теоретичної концепції патогенезу променевих ушкоджень. Кожен автор, який описував ті чи інші променеві ураження, пропонував якийсь свій термін (променеве ушкодження шкіри, рентгенівська еритема, рентгенівський дерматит, радіонекроз кісток, фіброз легень та інших органів, променеві виразки і променевий рак шкіри тощо). Поряд 3 місцевим опроміненням було відомо і про загальну дію опромінення (зміни зі сторони крові, обміну речовин, температурна реакція тощо). Вже через 6 років після відкриття рентгенівських променів появилось повідомлення щодо першої «променевої» смерті, а до 1907 р. в Америці було зареєстровано 7 смертельних випадків від променевих ушкоджень; у 1908 р. подібних випадків було уже 20 в Америці і 11 в Англії [3].

Тільки після першого застосування США ядерної зброї у війні з Японією у 1945 році вчені стали детально та системно аналізувати клінічні прояви променевого ураження, зіставляти їх 3 дозами опромінення. Американським та японським лікарям стало очевидно, що ушкодження, тримані постраждалими жителями, абсолютно однакові 3 ушкодженнями при сильному опроміненні рентгенівськими променями чи променями радію.

Вже тоді, у перші місяці після бомбардування, проводилося порівняння клінічних проявів захворювання 3 показниками периферичної крові, інколи 3 картиною кісткового мозку, останні, в свою чергу - 3 часом, який пройшов після опромінення [4]. Так стала вибудовуватися клінічна картина гострої променевої хвороби, діагностичне i прогностичне значення окремих симптомів і окремих показників крові.

Коли і як виник термін «гостра променева хвороба»? Цікаво, що термін «гостра променева хвороба» появився лише у середині 50-х років. Після нещасних випадків у лабораторіях i при роботі на атомних реакторах, після бомбардування японських міст і променевого ураження жителів Маршалових островів, у літературі, переважно американській, мова йшла про «гострий променевий синдром», «променевий синдром», «гостре променеве ураження», «променеве ураження організму», але не про гостру променеву хворобу. Останній термін, на наш погляд, став вживатися у середині 50-х років радянськими фахівцями і відображав власне їх методологічний підхід у питаннях патології, визначення хвороби. Заступник міністра охорони здоров'я СРСР, керівник Державної служби радіаційної безпеки i медико-санітарної служби радянської атомної промисловості А.Г. Бурназян (1906-1981) у передмові до відомої книги Л. Гемпельмана, Г. Лиско і Д. Гофмана «Острый лучевой синдром» (1954) писав: «Острый лучевой синдром» содержит весьма существенные 
методологические ошибки. Авторы стоят на локалистических позициях, рассматривая патологические изменения главным образом как результат действия ионизирующего излучения на клетку. При анализе лучевого заболевания авторы исходят из столь же узколокалистических представлений о болезни... В своем анализе лучевого заболевания и в своих выводах авторы игнорируют реакции целостного организма и особенно значение реакций нервной системы, что характерно для буржуазной науки вообще» [5]. Поняття «синдром» при визначенні хвороби у ті часи взагалі вживалося рідко. Тож радянські фахівці зупинилися на терміні «променева хвороба».

Мета дослідження. Розглянути внесок вчених Інституту фізіології імені о.о. Богомольця НАН України у розвиток уявлень щодо біологічної дії іонізуючого випромінювання, патогенезу, клініки, діагностики, лікування та профілактики гострої променевої хвороби.

Матеріали та методи дослідження. У дослідженні використано історичний і бібліосемантичний методи 3 метою повного розкриття питань становлення та розвитку радіаційної медицини, зокрема актуальних питань гострої променевої хвороби.

Результати дослідження та їх обговорення. Перші дослідження щодо вивчення променевої хвороби в Україні розпочалися ще у 20-30-ті роки. Вони стали проводитись в Українському рентгенорадіологічному інституті (Харків) і в Київському рентгено-радіологічному та онкологічному інституті, про що мова йтиме у наступних повідомленнях. Проте системні дослідження променевої патології стали проводитись вже тільки після Другої світової війни. Лідером у цих дослідженнях став Інститут фізіології імені О.О. Богомольця.

\section{Iнсmumym}

фізіологіï

імені О.О. Богомольця АН УРСР. Наукова школа профбесора О.О. Городецького

У післявоєнні роки проблеми гострої променевої хвороби в Україні вивчались у декількох медичних центрах. До найбільш ранніх та фундаментальних досліджень необхідно віднести ті, що виконувались в Інституті експериментальної біології і патології АН УРСР та Інституті клінічної фізіології АН УРСР (до 1953 р.), потім після об'єднання цих закладів в Інституті фізіології імені 0.0. Богомольця АН УРСР під керівництвом професора, члена- кореспондента АН УРСР Олексія Опанасовича Городецького (1897-1967) - завідувача сектором біофізики і радіобіології.

0.0. Городецький народився 1897 р. у с. Нові Костичі Самарської губернії у родині сільського вчителя. У 1916 р. закінчив гімназію і в цьому ж році вступив на медичний факультет Саратовського університету. У 1919 р. $з$ третього курсу був мобілізований до лав Червоної армії, служив у госпіталях як лікарський помічник. Тільки у 1922 p. повернувся до Саратова і в 1924 р. закінчив навчання. Більше 10 років працював лікарем у селах і містах Уральської області терапевтом і рентгенологом. Завідував першою в Башкирській АССР рентгенівською станцією (1936-1944). У 1935-41 рр. та 1943-44 рр. доцент Башкирського медичного інституту (м. Уфа). у 1940 р. захистив докторську дисертацію, присвячену вивченню функціональних порушень діяльності серця методом рентгенокімографії. У роки Другої світової війни працював у військових госпіталях, очолював рентгенологічні відділення. Розробив методику лікування вогнепальних поранень променевою терапією, використовуючи звичайний діагностичний рентгенівський апарат. У 1944 p. на запрошення академіка 0.0. Богомольця переїхав до Києва, завідував кафедрою рентгенології Київського інституту вдосконалення лікарів. У 1945 р. отримав вчене звання профессора. У 1957 р., коли організувалась кафедра медичної радіології цього інституту, очолював її (1957-1960) [6, 7]. 31944 p. 0.0. Городецький - науковий співробітник Інституту клінічної фізіології АН УРСР, у 1951-1953 рр. - завідувач відділом біофізики Інституту експериментальної біології і патології, у 1953-1964 рр.- завідувач лабораторії, 1965-1967 pp. - сектора біофізики Інституту фізіології АН УРСР [8].

Варто зауважити, що іще до об'єднання інститутів експериментальної біології та клінічної фізіології, серед наукових інтересів директора Інституту експериментальної біології і патології Олега Олександровича Богомольця (працював у 1946-1953 рр.) були проблеми гомотрансплантації тканин, вивчення механізмів дії переливання крові, патогенезу променевої хвороби [9]. У подальшому 0.0. Богомолець продовжував вивчати гостру променеву хворобу вже в Українському науково-дослідному інституті санітарно-хімічному інституті. У 50 -ті роки інші наукові відділи Інституту теж займались 
вивченням проблем гострої променевої хвороби - час такий тоді був, адже у США і Радянському Союзі проводились інтенсивні наукові і практичні роботи по створенню і випробуванню ядерної зброї. Паралельно працювали і медики, вивчаючи тоді ще не зовсім відомі ураження.

В Інституті експериментальної біології і патології разом 3 Олегом Богомольцем розпочав свою діяльність і Олексій Городецький, який принаймні у 1951-1953 р. вже був завідувачем відділу біофізики. Тісна співпраця 0.0. Городецького із завідувачкою лабораторії морфології Інституту фізіології академіком АН УРСР О.І. Смирновою-Замковою (1880-1962), патофізіологом, завідуючим лабораторією експериментальної ендокринології В.П. Комісаренком (1907-1993) та завідувачим відділом експериментальної цитології Інституту експериментальної біології і патології (з 1953 р. - Інституту фізіології АН УРСР імені 0.О. Богомольця) академіком АМН СРСР О.Д. Тимофієвським (1887-1985) надала 0.0. Городецькому унікальні можливості із всебічного вивчення патогенезу променевої хвороби. Вивчення механізму дії іонізуючого випромінювання колектив дослідників проводив на рівні фізичних, біохімічних та біологічних змін. Ознайомлення з їх працями, виконаними у 50 $\mathrm{x}$ роках, свідчить про глибину, різносторонність досліджень, вони стали основою сучасних уявлень щодо природи біологічної дії променевих уражень.

Перші публікації О.О. Городецького були присвячені вивченню впливу рентгенівських променів на функцію фізіологічної системи сполучної тканини та місце терапії антитоксичною сироваткою 0.О. Богомольця у корекції змін, що виникали при цьому $[10,11]$.

Разом із завідувачем відділом експериментальної цитології Інституту експериментальної біології і патології (3 1953 р. - Інституту фізіології АН УРСР імені 0.0. Богомольця) академіком АМН СРСР О.Д. Тимофєєвським (1887-1985), використовуючи запропонований останнім метод культивування клітин і тканин, вивчав вплив рентгенівських променів на експлантати пухлин людини [12]. Автори дослідження не відмітили різниці у чутливості нормальної і пухлинної тканини, що культивувалась in vitro, при рентгенівському опроміненні, як при одномоментному, так і при дробовому опроміненні [13].
Дослідженнями, проведеними в Інституті фізіології АН УРСР, було показано, що під впливом іонізуючої радіації в опроміненому організмі виникають ранні зміни електричної активності мозку (А.І.Даниленко, М.Д. Стеценко) і біохімічні зміни в тканинах мозку (А.Ф. Макарченко, Р.С.Златін) та інших органах, зокрема у шлунково-кишковому тракті (Є.Г.Моргун, П.А. Сакун, М.П. Станец), наднирниках (В.П. Комісаренко), порушується перетворення рибонуклеїнових кислот у дезоксирибонуклеїнову (М.Ф. Ліпкан), інші біохімічні зміни. Вони виникали вже через 1020 хвилин після опромінення експериментальних тварин рентгенівськими променями в дозах, що викливали променеву хворобу.

Встановлено, що в опроміненому організмі тварин суттєво знижується кількість нуклеїнових кислот у крові. Зниження перебувало у прямій залежності від дози опромінення. Максимальне падіння концентрації нуклеїнових кислот у крові відповідало періоду виражених клінічних симптомів променевої хвороби.

М.Ф. Ліпкан у 1958 р. видав монографію «Элементы радиационной биохимии», розраховану на слухачів і викладачів курсів підвищення кваліфікації вищих медичних навчальних закладів. У книзі узагальнено літературні дані та власний багаторічний досвід у відносно новій галузі медичних знань - радіобіології, i, зокрема, у іï відгалуженні радіобіохімії. Спеціальна глава присвячена доволі новим питанням - шляхам профілактики і нормалізації процесів обміну речовин при променевих ураженнях, питанням дієтичного харчування при променевій хворобі [14]. Морфологічні дослідження опромінених тварин проводилися разом 3 академіком O.I. Смірновою-Замковою. Разом 3 нею надруковано підсумкову статтю, присвячену механізмам дії іонізуючого випромінювання [15].

В останні роки 0.0. Городецький зі своїм колективом приділяв увагу вивченню інкорпорованих радіоактивних речовин. У 50 ті роки накопичився великий експериментальний і клінічний матеріал із застосування радіоактивного фосфору. Проводились чисельні порівняльні дослідження 0.0. Городецького та його учнів 3 особливостей дії рентгенівського випромінювання і радіоактивного фосфору 
(Є.Ю. Чеботарьов, I.М. Шур'ян, В.В. Андрющенко, Г.М. Рекун, С.А. Король) [16]. Перші праці 0.0. Городецького і його учня Є.Ю. Чеботарьова 3 вивчення дії радіоактивного фосфору появились на початку 50-х років. Одна 3 них присвячена вивченню його розприділення у здорових тварин і у тварин 3 прищепленною карциномою [17]. У другій праці проводилось порівняння дії на живий організм загального рентгенівського опромінювання опромінювання радіоактивним фосфором [18].

Вивчення дії радіоактивного фосфору на організм показало, що його реакція на опромінення бета-променями радіофосфору багато в чому схожа на опромінення гаммапроменями $\mathrm{i}$ рентгенівськими променями. Введення радіоактивного фосфору всередину організму викликає ушкодження, подібні до гострої променевої хвороби. Шляхом порівняльного вивчення дії $\mathrm{P}^{32} \mathrm{i}$ рентгенівських променів 0.0. Городецький відмітив певні особливості реакції організму на ці види випромінювання. Дія радіофосфору відрізнялась низкою особливостей біологічної дії на організм внаслідок тривалого і безперервного опромінення, поступового убування дії, нерівномірного розподілення в тканинах та органах, тривалістю періоду напіврозпаду i, на кінець, хімічною активністю і токсичністю самої речовини. Вивчалися різні радіоактивні препарати, найбільш повно радіоактивний фосфор. Встановлено, що у тварин, які отримували $\mathrm{P}^{32}$, ознаки променевого ураження розвивались більш повільно, ніж при опроміненні рентгенівськими променями; ранні реакції зазвичай не були такими вираженими. Ознаки загальної слабкості і виснаження у тварин спостерігались у більш пізні терміни. Такі особливості клінічного перебігу хвороби, що розвивалась більш повільно, залишали більше часу для заходів, спрямованих на зменшення тяжкості ушкодження.

I.M. Шур`ян вивчала зміни 3 боку периферичної крові і кісткового мозку при рентгенівському опроміненні у порівнянні 3 опроміненням радіоактивним фосфором. Ці зміни були однаковими в обох випадках, тільки при опромінені радіоактивним фосфором період найбільш важких порушень складу периферичної крові наступав пізніше, ніж при рентгенівському опроміненні. Аплазія кісткового мозку наступала раніше при опроміненні P32 [19]. У 1959 р. I.М. Шур'ян захистила кандидатську дисертацію «Реакции кроветворной системы животных на внутреннее облучение бета-лучами радиоактивного фосфора и внешнее облучение рентгеновскими лучами».

Продовжуючи порівняльні дослідження дії рентгенівського опромінення і дії Р32, I.M. Шур'ян, В.В.Андрющенко та Г.М. Рекун встановили, що опромінення Р 32 характеризувалось більш повільними темпами відновлювального періоду і більш вираженим та тривалим пригніченням всіх захисних сил організму, що виражалося в експериментальних тварин у їх загибелі внаслідок розвитку вторинних інфекцій у віддалені терміни (6-8-10 міс.). Використовуючи метод електронної мікроскопії, вони встановили своєрідний характер змін нормальної структури плазматичних клітин кісткового мозку опромінених тварин і повільне у порівнянні 3 іншими кровотворними елементами їх відновлення [20]. Продовжуючи порівняльне вивчення двох видів опромінення рентгенівських променів і радіоактивного фосфору, було показано, що пригнічення утворення антитіл більше виражено під дією P32 (С.А. Король).

Морфологічні дослідження, виконані в лабораторії морфології Інституту фізіології О.І. Смирновою-Замковою i A.В. Мельниченко виявили, що при опроміненні радіоактивним фосфором в експериментальних тварин спостерігались значні ураження судин, особливо мілких артерій і вен з розвитком гіперпластичного процесу в ендотелії i м'язовій оболонці, що нерідко призводило до повної закупорки просвіту судин. У великих судинах вражалася вся судинна стінка. Застосування гістохімічних методів дослідження дозволили авторам визначити найбільш ранні зміни в морфології тканевих структур, зокрема стан полісахаридів, РНК і ДНК тканин [21]. У дослідах на тканинних культурах і при морфологічних дослідженнях уражень лімфатичного апарату О.І. СмирноваЗамкова та 0.0. Городецький показали, що разом з деструктивним впливом іонізуючого випромінювання воно підвищувало регенеративну здатність тканин. Автори підкреслювали, що ушкодження випромінюванням пов'язано не тільки і не стільки з ушкодженням клітини, як із впливом на весь організм. Так, зовнішнє бетаопромінення Р32, що поглинається шкірою, викликає зміни не тільки в шкірі, але може 
викликати променеву хворобу і навіть смерть експериментальної тварини [22].

Вивчалася дія радіоактивного фосфору і в клініці при лікуванні різних пухлин. Крім певного лікувального ефекту, спостерігалися ускладнення - ушкодження кровотворної системи (лейкопенія i тромбоцитопенія), гостра променева хвороба, виникнення пухлин, лейкемії [23].

Одним із головних завдань, що стояли перед радіобіологією того часу, був пошук ефективних засобів профілактики та лікування уражень іонізуючим випромінюванням. Інститут фізіології імені 0.0. Богомольця АН УРСР був піонером у цих дослідженнях у Радянському Союзі.

Вивчаючи особливості біологічної дії Р32 при внутрішньому його застосуванні, 0.0. Городецький та його співробітники знайшли низку ефективних засобів для лікування гострої променевої хвороби, у тому числі спосіб виведення 3 організму радіоактивних ізотопів. Застосовувалися лімонокислий натрій, паратіреокрин, компалон, нуклеїнові кислоти, кобальтпептид, етилендіамінтетраоцтова кислота (ЕДТА), антиретикулярна цитотоксична сироватка (АЦС) 0.0. Богомольця, кровозамінник БК-8. Радіоактивний фосфор виводився з організму (до 30\%) при насиченні його нерадіоактивним фосфором [24, 25, 26].

У кінці 50-х років отримано факти, які дозволили уточнити погляди на патогенез променевої хвороби. Насамперед стала яснішою роль безпосередніх, прямих радіаційних пошкоджень біологічних структур. Було з'ясовано, що ці пошкодження, заподіянні в живій клітині опроміненням, можуть через деякий час повністю відновлюватися, що свідчило про поступову, розтягнуту в часі реалізацію променевих ушкоджень, отже, припускалась можливість зменшення розміру цих ушкоджень при цілеспрямованому втручанні, зокрема шляхом гальмування радіаційної деполімеризації ДНК, мітотичної активності клітин, вільнорадикальних процесів. Стало зрозумілим, що в патогенезі променевих пошкоджень істотну роль відіграють хімічні реакції, які розвиваються під впливом вільних радикалів, що утворюються в живих тканинах під впливом іонізуючої радіації. 3'ясовано роль кисню в патогенезі променевих ушкоджень. Їх тяжкість відповідала концентрації кисню в тканинах: якщо гіпоксія сприяла збільшенню виживання опромінених тварин, то збільшення концентрації кисню посилювало пошкоджуючу дію радіації.

3 метою зниження рівня окислювальновідновних процесів, кількості утворюваних в тканинах вільних радикалів 0.0. Городецький і В.А. Барабой запропонували застосовувати препарати галової кислоти та її похідні, що належали до групи інгібіторів вільно радикальних окисних процесів, крім того, позитивно впливали на обмін нуклеїнових кислот. Спочатку досліджувалася профілактична ефективність пропілгалату при гострій променевій хворобі, викликаній у мишей дозою 600 p i у щурів дозою 750 p. Виживання мишей склало 43\%, щурів - 40\%. При комбінації пропілгалату 3 цистеїном профілактична ефективність досягала 73\% [27].

Пізніше було показано, що застосування 3 лікувальною метою найбільш розчинного і швидко діючого натрійгалату приводило до виживання $50 \%$ опромінених тварин. Отримані дані дозволили провести попередні клінічні випробування натрійгалату з метою профілактики променевих ускладнень при рентген-радіотерапії злоякісних пухлин 3 позитивними результатами [28]. Пропонувалось застосовування препаратів галової кислоти в комбінації 3 іншими засобами лікування гострої променевої хвороби.

Ефективним виявилося і профілактичне застосування галатів. В експериментах було показано, що пропілгалат, введений перед опроміненням, збільшував тривалість життя опромінених тварин, відсував період розпалу клінічної картини гострої променевої хвороби.

Цікаво, що у механізмі антипроменевих ефектів препаратів різних хімічних груп 0.0. Городецький та його колектив вбачали спільну ланку, а саме - тканинну гіпоксію, яка не тільки зменшувала вихід активних радикалів при опромінюванні, а й знижувала інтенсивність обмінних процесів i, отже, радіочутливість окремих органів, систем i всього організму. На той час вже була відома досить представницька група препаратів 3 антипроменевими ефектами: ряд амінокислот і пептидів; препарати, що містили сірку (цистеїн, цистин, глютатіон); їх амінів (цистеамін, цистамін); препарати, що знижували концентрацію кисню в тканинах (нітрит натрію, метиленова синька, окис вуглецю тощо); препарати, що зв'язували активні радикали (глюкоза, деякі спирти, жирні кислоти, деякі аміни (глюкозамін, 
триптамін, фенамін, серотонін тощо). До цього ряду 0.0. Городецький відносив і препарати галової кислоти. [29, 30, 31].

В лабораторії біофізики Інституту фізіології 0.0. Городецьким і Е.3. Рябовою вперше були випробувані антипроменеві засоби в ряду заміщених ариламідів і головним чином арилгідразидів тіокарбонових кислот, синтезованих Інститутом органічної хімії АН УРСР П.С. Пелькісом. Сполуки цього ряду мали властивості, необхідні для антипроменевих речовин, крім того легко розчинялися у воді, що забезпечувало їм гарну проникність до всіх органів i систем організму. Найкращий профілактичний ефект щодо захисної дії від іонізуючого опромінення було отримано від динатрійової солі 1,5-ди-(4-сульфофенил) тіокарбогідразиду (препарат №12). У різних експериментальних тварин 3 гострою променевою хворобою його ефективність становила від 40 до 64\% [32].

Серед радіоактивних продуктів розпаду урану після вибуху атомної бомби найбільша увага приділялась радіоактивним ізотопам цезія і стронція, так як вони мали великий період напіврозпаду i інтенсивно забруднювали навколишнє середовище. Е.3. Рябовою проведено дослідження щодо виведення радіоактивного цезію-134 з організму за допомогою комплексоутворюючих речовин. Було встановлено, що найбільш ефективними засобами, які виводили радіоактивний цезій, виявилися щавелева кислота, лімонокислий натрій у поєднанні з глюконатом кальцію, котрі скорочували біологічний період напіврозпаду цезію у 5-6 разів. За матеріалами цього дослідження Е.3. Рябовою у 1959 р. була захищена кандидатська дисертація «Ускорение выведения радиоактивного цезия-134 из организма с помощью некоторых комплексообразующих веществ».

Комбіноване застосування препаратів (паратіреокрин, камполон, лімонокислий натрій) прискорювало виведення стронцію-89 3 організму, проте помітно не впливало на перебіг гострої і хронічної променевої хвороби [33].

В лабораторії експериментальної ендокринології (В.П. Комісаренко) ще у 1945 р. вдалося виділити в очищеному вигляді із селезінки рогатої худоби біологічно активний гормональний препарат - спленін - хімічна природа, фізіологічні та лікувальні якого вивчались в Інституті експериментальної біології та патології, а потім в Інституті фізіології імені 0.О. Богомольця АН УРСР. Випробуванням препарату при лікуванні експериментальної гострої променевої хвороби (Є.Ю. Чеботарьов) отримано позитивний ефект, значно збільшувалось виживання тварин (до 55\%), тоді як у групі контрольних доза опромінення в 700 p викликала загибель 85\% тварин. Відмічено також позитивний ефект лікування спленіном променевої реакції, яка появлялась після рентгенотерапії в онкологічних хворих [34, 35].

Лабораторія біофізики Інституту фізіології займала лідируючі позиції $\mathrm{y}$ Радянському Союзі 3 вивчення протипроменевих засобів. Вже у 1959 р. за редакцією 0.0. Городецького вийшла монографія «Выведение из организма некоторых радиоактивных веществ» (авторы - А.A. Городецкий, Т.П.Сиваченко, О.А. Хомутовский, Э.З. Рябова), у 1964 р. О.О. Городецкий, П.С. Пелькіс, Е.З. Рябова і Р.Г. Дубенко видали монографію «Противолучевые свойства ариламидов и арилгидразидов тиокарбоновых кислот». У 1971 р. В.А. Барабой видав книгу «Променеві ураження і механізми протипроменевого захисту», у 1976 р. він же - «Биологическое действие растительных фенольных соединений». Ці книги не втратили актуальності і в наші дні.

3 появою на початку 50-х років термоядерної зброї (нейтронної бомби), застосування ядерного синтезу при будівництві атомних електростанцій актуальним стало вивчення біологічної дії нейтронів. У 1960 р. в Києві було запущено дослідницький реактор ВBP-М 3 метою дослідження фізики нейтронів.

О.О. Городецьким, Б.Р. Киричинським і €.Ю. Чеботарьовим започатковано вивчення біологічної дії нейтронного опромінення на реакторі ВВР-М, встановленому у Київському інституті фізики АН УРСР. 3 метою визначення біологічної ефективності нейтронного i рентгенівського опромінення були проведені порівняльні дослідження їх дії на тварин та рослини у горизонтальному каналі атомного реактора ВВР-М. Було встановлено, що нейтрони давали більшу щільність іонізації, ніж рентгенівські чи гама-промені, наносять більш тяжкі ушкодження i для них відновлювальні процеси мають значно меншу роль, ніж для рентгенівських і гама-променів. Кінцевий біологічний ефект опромінення 
залежить не тільки від загальної величини поглинутої дозі і її потужності, але і від розподілу поглинутої енергї в органах i тканинах опроміненого організму. Низкою експериментів автори спостерігали пониження резистентності тварин до інфекцій та злоякісних новоутворень [36, 37].

0.0. Городецьким та його колективом вивчався вплив нейтронного опромінення на кровотворну, серцево-судинну системи, щитоподібну залозу і наднирники, на фізикохімічні властивості крові, на деякі мікроорганізми, розроблялись питання дозиметрії нейтронного опромінення. Проведені дослідження викладені у збірнику «Биологическое действие нейтронного излучения», що вийшов за редакцією 0.0 . Городецького у 1965 р. У 1961 р. колективом авторів (0.О. Городецький, Б.Р. Киричинський, М.Ф. Липкан) видана монографія «Очерки по радиобиологии», у якій у доступній формі викладено основні проблеми радіобіології: глава «Фізичні основи радіобіології» написана Б.Р. Киричинським, глава «Біологічна дія іонізуючого опромінення на живий організм» 0.0. Городецьким, глава «Обмін речовин при дії на організм іонізуючої радіації» М.Ф. Липканом .

Свідченням досягнень українських вчених в області радіології стала проведена у Києві (9-13 червня 1958 р.) наукова конференція «Действие ионизирующих излучений на животный организм» за участю відомих фахівців з усього Радянського Союзу, на якій були всебічно розглянуті питання променевої хвороби. За матеріалами конференції було видано збірник «Действие ионизирующих излучений на животный организм» за редакцію члена-кореспондента АН УРСР професора 0.0. Городецького. 21-24 червня 1960 р. у Києві була проведена наукова конференція з питань біофізики і механізму дії іонізуючої радіації за участю Інституту біофізики АН СРСР та АН УРСР (Інституту фізіології імені 0.0. Богомольця). Питання біологічної дії іонізуючої радіації і променевої хвороби розглядалися на II з'їзді онкологів і III з'їзді рентгенологів та радіологів УРСР у 1956 році, на IV з'їзді рентгенологів і радіологів УРСР у 1963 році.

Член-кореспондент АН УРСР (1957)

0.0. Городецький підготував більше 20 докторів і кандидатів медичних наук. Серед його учнів такі відомі у майбутньому біофізики, біохіміки, радіологи, як Є.Ю. Чеботарьов, М.Ф.Ліпкан, I.М. Шур'ян,
Т.П. Сіваченко, О.А. Хомутовський, В.А. Барабой, Е.З. Рябова, Б.Р. Киричинський та інші.

\section{Наукова икола професора \\ Є.Ю. Чеботарьова}

Творчий шлях відомого радіобіолога, доктора медичних наук, професора Є.Ю. Чеботарьова пройшов через декілька наукових закладів, проте початок його досліджень 3 вивчення біологічної дії іонізуючого опромінення та проблем гострої променевої хвороби розпочався з Інституту фізіології імені О.О. Богомольця АН УРСР.

Євген Юхимович Чеботарьов (1918$2005)$ народився у м. Азов, у 1938 р. вступив до 2-го Київського медичного інституту, у зв'язку з початком війни навчання закінчував уже у Дагестанському медичному інституті (1942). У роки війни - військовий хірург, начальник відділення евакуаційного госпіталю. У 19451948 рр. - навчання у клінічній ординатурі Інституту експериментальної біології та патології АН УРСР, де під керівництвом професорів I.М.Іщенка та 0.0. Городецького у 1952 р. захистив кандидатську дисертацію, присвячену лікуванню пухлин молочної залози (хірургічне та променеве). Недовго працював в Інституті молекулярної біології та генетики, потім в Інституті фізіології імені 0.0. Богомольця АН УРСР. Наукову роботу, присвячену дослідженню біологічної дії іонізуючого випромінювання та розробці ефективних методів лікування променевих уражень, проводив вже в Інституті експериментальної патології, онкології і радіобіології імені Р.Є. Кавецького АН УРСР, де завідував відділом радіобіології (1973-1985). У 1961 р. Є.Ю. Чеботарьов створив в Інституті фізики АН УРСР наукову групу з вивчення біологічної дії швидких нейтронів на атомному реакторі та прискорювачі У-240 і протягом 25 років проводив дослідження [38].

Його ранні дослідження присвячені вивченню перебігу (клініки) гострої променевої хвороби. Вони стосувались смертності собак при різній дозі рентгенівсього опромінення. Спостерігав чотири класичних періоди хвороби (початковий, латентний, період розпалу і період одужання). Підтвердив значні зміни картини крові, які вже були описані раніше. Спостерігав глибокі зміни у білковому обміні (гіпопротеїнемія, підвищення в крові залишкового азоту, загального і залишкового азоту в сечі), які свідчили про інтенсивний білковий розпад. Змінювався нуклеїновий обмін - підвищення 
дезоксирибонуклеазної активності сечі, особливо в період розпалу хвороби. Одужання супроводжувалося поліпшенням складу крові, зменшенням білкового розпаду і зниженням дезоксирибонуклеазної активності сечі [39].

Одне 3 перших його досліджень стосувалось вивчення білкового складу сироватки крові в динаміці на різних етапах променевої хвороби. Існуючі на той час літературні дані були досить суперечливими, частіше змінам фракційного складу білків при променевій хворобі не надавалось значення. Київським дослідником було встановлено, що у собак при гострій променевій хворобі спостерігалось виразне зменшення кількості альбумінів і збільшення вмісту глобулінів. Спостерігалась фазність змін фракцій білків у різні періоди променевої хвороби. Після опромінення утворювались додаткові альфа і бета-глобулінові фракції, які визначались і в наступних дослідженнях аж до загибелі тварин. Появу цих додаткових фракцій автор розглядав як несприятливий прогностичний фактор [40].

Вже на початку 60-х років стало зрозуміло, що найкращого терапевтичного ефекту у лікуванні гострої променевої хвороби можна досягнути шляхом застосування комплекса лікувальних засобів, спрямованих на різні патогенетичні ланки хвороби 41, 42]. Саме в Інституті фізіології імені 0.0. Богомольця АН УРСР під керівництвом професора 0.0. Городецького Євген Чеботарьов розпочав дослідження 3 променевої хвороби. 0.0. Городецький був науковим консультантом його докторської дисертації «Экспериментальное исследование комплексных методов лечения острой лучевой болезни» (1966).

Є.Ю. Чеботарьов став автором і першої в СРСР грунтовної монографії, присвяченої променевій хворобі - «Комплексное лечение острой лучевой болезни» (1965), у якій детально зупинився на власних дослідженнях та даних літератури щодо біологічної дії іонізуючої радіації, клініки променевої хвороби та їі лікування.

Враховуючи складний патогенез хвороби i різноманіття клінічних синдромів, комплексна терапія мала включати засоби, що впливають на всі ланки патогенезу і основні синдроми: ураження кровотворення, геморагічний, шлунково-кишковий та інфекційний. У монографії наведено великий експериментальний матеріал із дослідження лікувальних властивостей препаратів крові, кровозамінника БК-8 та деяких стимуляторів кровотворення, а також антибіотиків. Автор детально розглянув вплив трансплантації кісткового мозку на перебіг променевої хвороби, зупинився на власному досвіді трансплантацій в експерименті.

Досліджував ефективність лікування в залежності від тяжкості перебігу променевої хвороби. При помірних дозах опромінення, коли регенерація кровотворення настає відносно рано, підтримуючої терапії (антибіотики, вітаміни, кров і препарати крові, білкові замісники крові), як правило, було достатньо, аби справитись 3 хворобою.

Розроблені автором методи комплексного лікування в експерименті було рекомендовано для лікування променевого ураження людей. Багато з цих рекомендацій, зокрема сам принцип комплексного лікування, були використані вітчизняними лікарями при лікуванні променевої хвороби у постраждалих у роки Чорнобильської катастрофи. Розвиток ядерної енергетики, мережі експериментальних нейтронних реакторів, нейтронних прискорювачів, поява у 60-70-х роках нейтронної зброї (нейтронної бомби) стимулювали дослідження 3 вивчення біологічної дії нейтронного опромінення, особливостей перебігу i лікування гострої променевої хвороби, що викликалась дією нейтронів.

У результаті співпраці Інституту фізіології 3 Інститутом фізики АН УРСР (Інститут ядерних досліджень АН УРСР) у вчених появилась можливість проводити експериментальні дослідження впливу нейтронного опромінення на організм тварин, створення моделі гострої променевої хвороби (тварини опромінювались швидкими нейтронами у горизонтальному каналі атомного реактора ВВР-М) і вивчення захисної дії екзогенної ДНК. Променева хвороба, що викликалась швидкими нейтронами, характеризувалась більш глибокими змінами в генетичному матеріалі (ДНК), всіх обмінів речовин опромінених тварин.

Швидкі нейтрони у порівнянні 3 рентгенівським i гама-опроміненням призводили до більш глибоких уражень системи крові, які довго не відновлювались. Порушення в обміні нуклеїнових кислот були однією з причин бластомогенної дії цього виду радіації.

Є.Ю. Чеботарьов, як учень 0.0. Городецького, проводив успішні дослідження 3 вивчення протипроменевих засобів. Одним із ефективних профілактичних і 
лікувальних препаратів при променевій хворобі довгі роки залишалась екзогенна ДНК. Раніше було відомо щодо захисної дії екзогенної ДНК при опроміненні тварин рентгенівськими і гамма-променями. Є.Ю.Чеботарьов, Е.З. Рябова вперше вказали на захисну та лікувальну дію екзогенних нуклеїнових кислот, зокрема полімерної ДНК, при променевій хворобі, яка викликалась швидкими нейтронами [43].

Вивчення захисної та лікувальної дії ДНК дозволило авторам припустити наступний механізм радіопротективної дії нуклеїнових кислот: а) активація клітинного метаболізму і в першу чергу біосинтезу білка; б) ослаблення радіохімічного розпаду нуклеїнових кислот шляхом активного з'вязування ДНК-аз, та радіотоксинів, що вивільнились у процесі дії іонізуючого випромінення. На рівні організму має значення неспецифічна стимуляція нуклеїновими кислотами імунологічної реактивності, у результаті чого відбувається підвищення радіорезистентності організму. Групою дослідників (Є.Ю. Чеботарьов, Є.3. Рябова, В.М. Індик) у 1974 р. було видано монографію «Защитное действие экзогенной ДНК при облучении быстрыми нейтронами».

У подальшому колектив авторів на чолі з Є.Ю. Чеботарьовим вже у відділі радіобіології Інституту проблем онкології імені Р.Є. Кавецького вивчали речовини 3 ряду заміщених ариламідів і арилгідразидів тіокарбонових кислот (препарати № 26 і № 12) як радіопротектори при опроміненні експериментальних тварин швидкими нейтронами. Серед синтезованих в Інституті органічної хімії АН УРСР арилпохідних триазолу i тетразолу виявлено низку ефективних радіопротекторів. Найбільшою радіозахисною активністю відрізнявся 1-nхлорфенілтетразол тіон-2, який забезпечував $57 \%$ виживання тварин при 100\%-ній смертності контрольних. Вказані препарати виявляли і певні лікувальні властивості на перебіг променевої хвороби.

Цією ж групою дослідників (Чеботарьов Є.Ю., Барабой В.А., Дружина М.О. та ін.) було показано, що речовини-антиоксиданти мають не тільки радіозахисні властивості, а навіть більше - пострадіаційну дію, i їх можливо використовувати як засоби патогенетичної терапії променевих уражень. У комплексі засобів патогенетичної терапії гострої променевої хвороби рекомендувались засоби, які пом'якшували прояви променевої гіперсекреції глюкокортикоїдних гормонів - препарати женьшеню, елеутерококу та інші адаптогени; антагоніст глюкокортикоїдів інсулін. У 1982 р. колективом співробітників відділу радіобіології Інституту проблем онкології імені Р.Є.Кавецького АН УРСР i Інституту ядерних досліджень АН УРСР видана монографія «Нейтрони и организм» за редакцією Є.Ю. Чеботарьова, у 1986 р. «Окислительные процессы при гамманейтронном облучении организма» (авторы Чеботарев Е.Е., Барабой В.А., Дружина Н.А. и др. Под общ. Ред.Чеботарева Е.Е.), у яких узагальнено і систематизовано багаторічні експериментальні дані досліджень, проведених на ядерному реакторі ВВР-М.

Визнанням досягнень українських вчених в області радіобіології, зокрема у вивченні проблем променевої хвороби, стало проведення у Києві (1968 рік) симпозиуму «Действие ионизирующей радиации на белки и нуклеиновые кислоты. Молекулярные механизмы защиты», організованого Інститутом фізіології ім. 0.0. Богомольця. Матеріали симпозиуму видані за редакцією Є.Ю. Чеботарьова і Б.Р. Киричинського.

Є.Ю. Чеботарьову належать численні публікації з радіобіології, він створив власну наукову школу радіобіологів, яка об’єднала лікарів, біологів, фізиків, хіміків та інших фахівців. У цій науковій школі було підготовлено 8 докторів і понад 20 кандидатів наук. До них можна віднести таких відомих вчених, як Я.I. Серкіз, М.О. Дружина, які очолювали відділ радіобіології Інституту проблем онкології імені Р.Є. Кавецького після свого вчителя протягом 20 років.

\section{Б.М. Раєвський - видатний біофізик українського походження}

Мало відомо, що визначальне значення для розуміння природи клінічних проявів гострої променевої хвороби мали дослідження українця за походженням біофізика Б.М. Раєвського (1893-1974).

Борис Миколайович Раєвський народився у м. Чигирині Київської губернії, навчався в Університеті Св. Володимира (Київ). До 1920 р. - старший ассистент у Київському університеті. Емігрував до Німеччини у 1927 році, працював профессором біофізики у Франкфуртському університеті, директором Інституту біофізики Товариства кайзера Вільгельма з розвитку науки у Франкфурті-наМайні (1937-1966). Працював в області радіології, радіобіології, біофізики високих частот і надзвуку. Перший запропонував термін «біофізика». Його іменем названо Біофізичний 
інститут у Саарбрюкене, Європейською асоціацією радіологів запроваджено медаль імені Бориса Раєвського [44].

Основна праця Б.М. Раєвського щодо дії іонізуючого випромінювання на живий організм - «Дозы радиоактивных излучений и их действие на организм» виходила у Радянському Союзі у 1954, 1956 і 1959 роках. У цих книгах вперше у російськомовній літературі автор привів систематизовані i схематично викладені симптоми гострої променевої хвороби у людини після короткочасного загального опромінення (гамма-опромінення) в залежності від часу, що пройшов після опромінення $(1,2,3,4$ тиждень) та від дози опромінення (сублетальна - 100 р, середня летальна - біля 400 р, летальна - біля 700 р). Детально описав розгорнуту картину основних клінічних синдромів при променевій хворобі в залежності від періоду хвороби (ранні реакції, період без симптомів, період виражених симптомів, віддалений період). Опираючись на дослідження, проведені у Японії у 1945 році і випадки опромінення при аваріях в американських атомних лабораторіях, зробив висновок відносно відповідності основних клінічних синдромів в опромінених i отриманою дозою опромінення. Тобто, знаючи симптоми і час їх появлення у людини, можна зробити висновок щодо отриманої дози опромінення, визначити ступінь тяжкості хвороби.

Б.М. Раєвським вивчено особливості розвитку променевої хвороби при нерівномірному загальному опроміненні, при опроміненні окремих частин тіла i при інкорпорації різних радіоактивних речовин. При всіх цих умовах опромінення встановив закономірності зміни крові, визначив їі показники для діагностики ступеня тяжкості променевої хвороби та її прогнозу. Зміни кількості у периферичній крові тих чи інших видів клітин виявляються тим раніше, чим коротша тривалість їх життя. Так, раніше всього виявляються зміни у числі клітин 3 найбільш коротким періодом життя лейкоцитах і тромбоцитах. Відносно повільно проявляється реакція зі сторони еритроцитів.

Б.М. Раєвський показав, що біологічна дія іонізуючого опромінення залежить не тільки від дози, тобто величини поглинутої енергії (виміряної в рентгенах чи радах), але і від виду самого опромінення (альфа, бета, гаммапромені, жорсткі рентгенівські промені, м'які рентгенівські промені, швидкі нейтрони). Чим більша біологічна дія даного виду опромінення, тим менша необхідна доза опромінення для отримання певної дії.

Значне місце у книзі Б.М. Раєвського відведено допустимим величинам радіоактивних ізотопів у тілі людини i допустимим концентраціям ізотопів у продуктах харчування, воді і повітрі. Особлива глава присвячена особливостям вражаючих факторів ядерної i термоядерної бомб, в залежності від виду вибуху (наземний, повітряний). Наукова цінність (не тільки історична) монографії Б.М. Раєвського зберігається і сьогодні [45]. Майже все, що ми сьогодні знаємо про гостру променеву хворобу у класичному їі розумінні, - завдяки нашому земляку, видатному вченому світового рівня Б.М. Раєвському.

Спираючись на систематизовані Б.М. Раєвським дані літератури та його власні дослідження щодо співвідношення біологічних ефектів з дозою опромінення, відома радянська дослідниця променевої хвороби А.К. Гуськова у 1964 році запропонувала класифікацію променевої хвороби, яка зберігається у науковому i практичному вжитку і сьогодні [46].

\section{Є.Б. Закржевський \\ Професор, полковник медичної служби}

Основним центром 3 питань гострої променевої хвороби у Радянському Союзі був клінічний відділ Інституту біофізики МО3 СРСР, створений у 1951 р., що розміщувався на базі Московської клінічної лікарні № 6.

Засновником клініки і її першим керівником став професор М.О. Куршаков (1951-1964). Пізніше клінічний відділ очолювали: професори В.С. Смоленський (19641966), А.І. Воробйов (1966-1974), А.К. Гуськова (1974-1996). Після декількох реорганізацій Інституту біофізики і його клінічного відділу було створено Федеральний медичний біофізичний центр імені А.Г. Бурназяна [17]. Варто зазначити, що перше повідомлення про успішне лікування гострої променевої хвороби у Радянському Союзі відбулося у 1954 р. А.К. Гуськовою і Г.Д. Байсоголовим (два випадки) на I-ій Міжнародній конференції 3 мирного використання атомної енергї в Женеві. У 195455 рр. були також перші таємні публікації 3 гострої променевої хвороби.

Другим центром для лікування хворих 3 гострою променевою хворобою у Радянському Союзі стала кафедра воєнно-польової терапї Військово-медичної академї імені С.М. Кірова, куди направлялися військовослужбовці, які отримали радіаційні ураження при аваріях, як 
правило, на флоті. Одним із перших начальників кафедри, який організував лікування постраждалих від радіації при аварії на атомному підводному човні ВМФ СРСР (К19) у 1961 р., став професор Є.Б. Закржевський (1909-1973).

Євгеній Броніславович Закржевський народився у м. Ніжині, закінчив Київський медичний інститут, працював на кафедрі пропедевтики внутрішніх хвороб, учень професора М.М. Губергріца. Після Другої світової війни служив у Київському військовому госпіталі (начальник терапевтичного відділення, начальник експериментальної лабораторії, провідний терапевт). У подальшому - головний терапевт Далекосхідного військового округу, старший викладач кафедри факультетської терапії (з гематологічною клінікою) Військово-медичної академії імені С.М. Кірова, начальник кафедри воєнно-польової терапії цієї Академії.

У результаті аварії на К-19 весь екіпаж човна отримав променеві ураження різної ступені важкості. Частина моряків з великими дозами опромінення, та ті, що мали поєднаний характер ураження (зовнішнього та внутрішнього) поступили до клініки військовопольової терапії. Не дивлячись, що це був перший досвід лікування таких уражених, на відсутність ефективних методів лікування, колектив кафедри справився із цим викликом, більше половини важких хворих залишились живими. Допоміг і досвід роботи Євгенія Броніславовича у гематологічній клініці. Сам начальник кафедри був першим, хто запропонував свій кістковий мозок для трансплантації хворому гострою променевою хворобою. Досвід, отриманий при лікуванні радіаційних уражень моряків, було ретельно вивчено та проаналізовано. Він став корисним при наданні допомоги хворим 3 гострою променевою хворобою у наступні роки та був використаний при підготовці керівних та нормативних документів 3 радіаційних уражень.

Є.Б. Закржевському (у співавторстві 3 працівниками кафедри) належать праці: «0 некоторых принципах лечения острой лучевой болезни» (1961), «Лучевая болезнь от внутреннего облучения» (1962), «Некоторые вопросы диагностики и лечения острой лучевой болезни» (1965). Викладач кафедри Г.І. Алєксєєв у 1964 р. на означеному матеріалі захистив докторську дисертацію, присвячену клініці, діагностиці та лікуванню гострої променевої хвороби. Знання і досвід
Г.I. Алєксєєва виявились корисними при наданні медичної допомоги ліквідаторам аварії на ЧAEC, ураженим іонізуючим випромінюванням.

Є.Б. Закржевським виказані цінні пропозиції щодо надання терапевтичної допомоги ураженим радіаційним випромінюванням у ході можливої війни із застосуванням ядерної зброї. Зокрема вніс пропозиції щодо підходів до лікування комбінованих уражень (пропонував збільшити чисельність терапевтів у хірургічних госпіталів, а хірургів - у терапевтичних), підкреслював, що незважаючи на умови бойової обстановки необхідно прагнути до надання максимальної допомоги постраждалому на кожному з етапів медичної допомоги. Вніс важливі пропозиції щодо сортування терапевтичних хворих в умовах застосування зброї масового ураження [47].

Таким чином, в першому повідомленні розглянуто вклад вчених Інституту фізіології імені 0.0. Богомольця НАН України у розвиток уявлень щодо біологічної дії іонізуючого випромінювання, патогенезу, клініки, діагностики, лікування та профілактики гострої променевої хвороби (наукові школи 0.О.Городецького, Є.Ю.Чеботарьова. німецький біофізик українського походження Б.М.Раєвський, професор Є.Б. Закржевський).

\section{Висновки}

1. Українськими вченими Інституту фізіології імені 0.0. Богомольця АН УРСР та окремими дослідниками - українцями за походженням (Б.М. Раєвський, Є.Б. Закржевський) розроблені важливі наукові напрями 3 вивчення гострої променевої хвороби (зроблено певний внесок у вивчення патогенетичних механізмів, детально описано розгорнуту картину основних клінічних синдромів; обгрунтовано принцип комплексного, патогенетичного лікування гострої променевої хвороби; винайдено, вивчено та застосовано низку ефективних протипроменевих засобів, різних механізмів дії, що мають як радіозахисні властивості, так i знижують ступінь променевого ураження організму ).

2. Результати наукових напрацювань цих вчених отримали визнання i практичне застосування при лікуванні постраждалих під час аварії на Чорнобильській АЕС.

3. Завдячуючи досягненням українських вчених були сформовані сучасні уявлення щодо гострої променевої хвороби. 


\section{Література}

1. Радиация: риски, безопасность, защита/Хабрhabr. Електронний peсурс. Режим доступу: habr.com>post.

2. Григор'єв С. П. - Історія Харкова у пам'ятних дошках. Електронний ресурс. Режим доступу: http://mevorydoskikharkov.blogspot.com.

3. Гамалея А.Н., Донской М.Д. Острая лучевая болезнь. Военно-медицинский журнал. 1954. № 10. С. 10

4. Действие атомной бомбы в Японии. Под редакцией Э. Отерсона и Ш. Уоррена. М., 1960. 414 С.

5. Бурназян А. Предисловие к русскому изданию.У кн.: Л.Гемпельман, Г. Лиско, Д. Гофман. Острый лучевой синдром. М., 1954. С. 3.

6. Чеботарев Е.Е. К 60-летию со дня рождения члена-корреспондента Академии наук УССР проф. A.А. Городецкого. Вестник рентгенологии радиологии. 1957. № 6. С. 88

7. Арендаревський Л.Ф. Городецький Олексій Опанасович. Енциклопедія сучасної України. Том 6. К. 2006. C. 288

8. Інститут фізіології імені 0.0. Богомольця НАН України. Електронний ресурс. Режим доступу: uk.wikipedia.org.> wiki>iнст...

9. Костюк П.Г., Мойбенко О.О., Березовський В.Я. Олегу Олександровичу Богомольцю було б уже 90 років. Фізіологічний журнал . 2001. № 4. С. 72-77.

10. Городецкий А.А. и Спасокукоцкий Ю.А. Функциональные изменения физиологической системы соединительной ткани под влиянием рентгеновских лучей и последующей АЦС-терапии. В сб. Злокачественные новообразования и борьба с ними. Киев-Харьков. 1945. С. 114-120.

11. Городецкий А.А. Влияние рентгеновых лучей на функцию физиологической системы соединительной ткани. Сб. трудов Киевск. ин-та усоверш. врачей, 1950. вып. 1. С. 18-22.

12. Тимофеевский А.Д. и Городецкий А.А.Действие лучей Рентгена на эксплантаты опухолей человека. Учен. записки Киевск. н.-и. рентгено-радиол и онкол. ин-та. К., 1949. 1. С. 165-184.

13. Тимофеевский А.Д., Городецкий А.А., Чалая М. Изучение сравнительного действия рентгеновых лучей при однократном и многократном облучении эксплантантов нормальной и опухолевой ткани человека. Вестник рентгенологии и радиологии. 1963. № 6. C. 15-22.

14. Липкан Н.Ф. Элементы радиационной биохимии. К., 1958. 158 С.

15. Смирнова-Замкова А.И., Городецкий А.А. О механизме действия ионизирующих проникающих излучений. Врачебное дело. 1954. № 6. С. 500-504.

16. Городецкий А.А. Особенности биологического действия радиоактивного фосфора. Труды II съезда онкологов и III съезда рентгенологов и радиологов УССР 18-24 июня 1956 г. К., 1959. С. 171-175.

17. Городецкий А.А. и Чеботарев Е.Е. Распределение радиоактивного фосфора у нормальных кроликов и у кроликов с перевитой карциномой. Вестник рентгенологии и радиологии. 1954. № 3. 7-13.

18. Чеботарев E.E. Действие общего рентгеновского облучения и внутреннего облучения радиоактивным фосфором на экспериментальных животных. - В кн.: Опыт применения радиоактивных изотопов в медицине. Киев. 1955. 149-152.

19. Шур'ян I.М. Вплив зовнішнього і внутрішнього опромінювання на периферичну кров і кістковий мозок кроликів. Фізіологічний журнал. 1955. № 3. С. 109-117.

20. Шурьян И.М., Андрющенко В.В., Рекун Г.М. Особенности реакции кроветворной системы в период восстановления ее функции после радиационного поражения. В кн.: Восстановительные процессы при радиационных поражениях. М., 1964. С. 164-170.

21. Смирнова-Замкова А.И., Мельниченко А.В., Олейникова Т.Н. К вопросу о гистохимических изменениях тканей при действии ионизирующих излучений. У кн.: Материалы научной конференции по вопросам биофизики и механизма действия ионизирующей радиации 21-24 июня 1960 г. К., 1960. С. 165-166.

22. Городецкий А.А. Особенности биологического действия радіоактивного фосфора. Труды II съезда онкологов и III съезда рентгенологов и радиологов УССР 18-24 июня 1956 г. К., 1959. С. 171-175.

23. Чеботарев Е.Е. К 60-летию со дня рождения члена-кореспондента АН УРСР проф. А.А. Городецкого. Вестник рентгенологии и радиологии. 1954. № 6. C. 574

24. Сиваченко Т.П., Рябова Э.З., Хомутовский О.А. Применение некоторых препаратов, ускоряющих выведение радиоактивных изотопов (фосфора, цезия и стронция) из организма. Труды II съезда онкологов и III съезда рентгенологов и радиологов УССР 18-24 июня 1956 г. К., 1959. С. 256-258.

25. Городецкий А.А., Чеботарев Е.Е. О терапии лучевой болезни. Новый хирургический архив. 1959. №4. С. 3-12.

26. Городецкий А.А. Актуальные вопросы изучения биологического действия ионизирующей радиации на животный организм. В кн.: Действие ионизирующих излучений на животный организм. К., 1960. С. 7-16.

27. Городецкий А.А., Барабой В.А., Чернецкий В.П. Защитное действие некоторых ингибиторов цепных окислительных процессов при острой лучевой болезни. В кн.: Материалы научной конференции по вопросам биофизики и механизма действия ионизирующей радиации 21-24 июня 1960 г. К., 1960. C. $44-45$.

28. Городецкий А.А., Барабой В.А. Натрийгаллат новое средство профилактики и лечения острой лучевой болезни. У кн.: IV съезд рентгенологов и радиологов Украинской ССР. Тезисы докладов. КиевХарьков, 1963. С. 324.

29. Городецкий А.А. Действие фенамина на течение лучевой болезни. Тезисы докладов на научн. сессии, посв. 30-летию деят. Центр. н.-и. ин-та рентгенол. и радиол. им. В.М. Молотова. М., 1954. 16.

30. Городецький A.А., Барабой B.A. Хіміопрофілактика і хіміотерапія експериментальної гострої променевої хвороби. Фізіологічний журнал АН УРСР. 1961. № 5. C. 617-624.

31. Городецький О.А., Барабой В.А., Чернецький В.П. Захисна дія деяких інгібіторів ланцюгових окислювальних процесів при гострій променевій хворобі. Доповіді АН УРСР. 1961. № 6. С. 812-815

32. Городецкий А.А., Пелькис П.С., Рябова Э.З., Дубенко Р.Г. Противолучевые свойства ариламидов и 
арилгидразидов тиокарбоновых кислот. К., 1964. 111 C.

33. Городецкий А.А., Хомутовский О.А., Рябова Э.З. Экспериментальная профилактика и терапия лучевой болезни, вызванной внешним и внутренним облучением. В кн.: Медицинская радиология. Труды Всесоюзной конференции по применению радиоактивных и стабильных изотопов и излучений в народном хозяйстве и науке. 4-12 апреля 1957 г. М., 1960. С. 275-281.

34. Комісаренко В.П. Спленін, його біологічні і лікувальні властивості. Фізіологічний журнал. 1960. № 5. С. 672-689.

35. Чеботарев Е.Е. Применение спленина в эксперименте и клинике при лучевых повреждениях. В кн.: Материалы научной конференции по вопросам биофизики и механизма действия ионизирующей радиации 21-24 июня 1960 г. К., 1960. С. 193-194.

36. Городецкий А.А., Киричинский Б.Р., Чеботарев E.E. Об относительном биологическом действии нейтронного облучения. У кн.: IV съезд рентгенологов и радиологов Украинской ССР. Тезисы докладов. Киев-Харьков. 1963. С. 262-263.

37. Городецкий А.А., Киричинский Б.Р., Чеботарев E.E. Об относительной биологической эффективности быстрых нейтронов. У кн.: Биологическое действие быстрых нейтронов. Под редакцией А.А. Городецкого. К., 1969. Вып. 1. С. 3-13.

38. Виноградова Р.П., Данилова В.М. Лауреати премії НАН України імені О.В.Палладіна 1995-1996. Український біохімічний журнал. 2014. № 2. С.142143.

\section{References}

1. Radiation: risks, safety, protection / Habr-habr. Electronic resource. Access mode: https://habr.com/ru/post/444392/

2. Grigor'ev, S. P. History of Kharkov at the memorial plaques. Electronic resource. Access mode: http://mevorydoskikharkov.blogspot.com/2016/05/ blog-post 5.html

3. Gamaleya, A.N., Donskoy, M.D. (1954). Acute radiation sickness. Military Medical Journal. 10, 10.

4. Action of the atomic bomb in Japan. (1960). Edited by E. Oterson and S. Warren. M, 414.

5. Gempelman, L., Lisko, G., Hoffman D. (1954). Acute radiation syndrome. Study of 9 cases and an overview of the problem: transl. from English / with a foreword. A. Burnazyan. Moscow: Publishing house of foreign. lit., 290.

6. Chebotarev, E.E. (1957).To the 60th anniversary of the birth of Corresponding Member of the Academy of Sciences of the Ukrainian SSR prof. A.A. Gorodetsky. Bulletin of radiology radiology. 6, 88.

7. Arendarevsky, L.F. (2006). Gorodetsky Oleksiy Opanasovich. Encyclopedia of Successful Ukraine. Volume 6.K., 288.

8. Bogomoletz Institute of Physiology. Electronic resource. Access mode: https://en.wikipedia.org/wiki/Bogomoletz Institute of Physiology.

9. Kostyuk, P.G., Moybenko, O.O., Berezovsky, V.Ya. (2001). Oleg Oleksandrovich Bogomolets was already 90 years old. Physiological journal, 4, 72-77.
39. Чеботарьов Є.Ю. Перебіг гострої променевої хвороби у собак. Фізіологічний журнал. 1960. № 5. С. 652-658

40. Чеботарьов Є.Ю. Зміна білкових фракцій сироватки крові у собак при гострій променевій хворобі. Фізіологічний журнал АН УРСР. 1961. № 1. С. 83-91.

41. Липкан Н.Ф., Пиндич М.Т. О нормализации некоторых обменных процессов у животных, облученных рентгеновыми лучами и леченных комплексным методом. У кн.: IV съезд рентгенологов и радиологов Украинской ССР. Тезисы докладов. Киев-Харьков, 1963. С. 325.

42. Чеботарев Е.Е. Опыт комплексного лечения острой лучевой болезни в эксперименте. Там же. С. 326-327.

43. Чеботарев Е.Е., Рябова Э.З. Защитные свойства гомологичной ДНК при облучении животных быстрыми нейтронами. $\mathrm{y}$ кн.: Действие ионизирующей радиации на белки и нуклеиновые кислоты. Молекулярные механизмы защиты. К., 1970. - C. 238-242.

44. Раєвський Борис Миколайович. Електронний pecypc. Режим доступу: https://.wikipedia.org>wiki

45. Раевский Б. Дозы радиоактивных излучений и их действие на организм. М., 1959. 205 С.

46. Гуськова А.К., Байсоголов Г.Д. Лучевая болезнь человека. - М., 1971. - С. 22.

47. Бойчак М.П. Нариси 3 історії української військової терапії. Книга 2. К., 2020. С. 216-221.

10. Gorodetsky, A.A. and Spasokukotsky, Y.A. (1945). Functional changes in the physiological system of the connective tissue under the influence of X-rays and subsequent ACS therapy. On Sat. Malignant neoplasms and the fight against them. Kiev-Kharkov. 114-120.

11. Gorodetsky, A.A. (1950). Influence of X-rays on the function of the physiological system of the connective tissue. Collection of works Kievsk. Institute of doctors Improvement, 1,18-22.

12. Timofeevsky, A.D. and Gorodetsky A.A. (1949). The action of X-rays on human tumor explants. Scientist. notes Kievsk. Inst. X-ray radiol and oncol. K., 1, 165-184.

13. Timofeevsky, A.D., Gorodetsky, A.A., Chalaya, M. (1963). Study of the comparative effect of X-rays in single and multiple irradiation of explants of normal and tumor human tissue. Bulletin of radiology and radiology, 6, 15-22.

14. Lipkan, N.F. (1958). Elements of radiation biochemistry. K., 158.

15. Smirnova-Zamkova, A.I., Gorodetsky, A.A. (1954). On the mechanism of action of ionizing penetrating radiation. Medical business, 6, 500-504.

16. Gorodetsky, A.A. (1956). Features of the biological action of radioactive phosphorus. Proceedings of the II Congress of Oncologists and the III Congress of Radiologists and Radiologists of the Ukrainian SSR June 18-24, K., 171-175.

17. Gorodetsky, A.A. and Chebotarev, E.E. (1954).Distribution of radioactive phosphorus in 
normal rabbits and in rabbits with transplanted carcinoma. Bulletin of radiology and radiology, 3, 7-13.

18. Chebotarev, E.E. (1955). The effect of general Xray irradiation and internal irradiation with radioactive phosphorus on experimental animals. - In the book: Experience in the use of radioactive isotopes in medicine. Kiev. 149-152.

19. Shuryan, I.M. (1955).The inflow of a lasting and internal optimization into the peripheral roof and cystic brain of rabbits. Physiological journal, 3, 109-117.

20. Shuryan, I.M., Andryushchenko, V.V., Rekun, G.M. (1964). Features of the reaction of the hematopoietic system during the recovery of its function after radiation injury. In the book: Recovery processes in radiation injuries. M., 164-170.

21. Smirnova-Zamkova, A.I., Melnichenko, A.V., Oleinikova, T.N. (1960). On the question of histochemical changes in tissues under the action of ionizing radiation. In the book: Materials of a scientific conference on biophysics and the mechanism of action of ionizing radiation June 21-24, K., 165-166.

22. Gorodetsky A.A. (1956). Features of the biological action of radioactive phosphorus. Proceedings of the II Congress of Oncologists and the III Congress of Radiologists and Radiologists of the Ukrainian SSR June 18-24, K., 171-175.

23. Chebotarev, E.E. (1954). On the occasion of the 60th anniversary of the birth of Corresponding Member of the Academy of Sciences of the URSR prof. A.A. Gorodetsky. Bulletin of radiology and radiology, 6, 574.

24. Sivachenko, T.P., Ryabova, E.Z., Khomutovsky, O.A. (1959). The use of certain drugs that accelerate the elimination of radioactive isotopes (phosphorus, cesium and strontium) from the body. Proceedings of the II Congress of Oncologists and the III Congress of Radiologists and Radiologists of the Ukrainian SSR June 18-24, 1956, K., 256-258.

25. Gorodetsky, A.A., Chebotarev, E.E. (1959). On the therapy of radiation sickness. New surgical archive, 4, 312.

26. Gorodetsky A.A. (1960). Topical issues of studying the biological effect of ionizing radiation on an animal organism. In the book: The effect of ionizing radiation on the animal organism. K., 7-16

27. Gorodetsky, A.A., Baraboy, V.A., Chernetsky, V.P. (1960). Protective action of some inhibitors of chain oxidative processes in acute radiation sickness. In the book: Materials of a scientific conference on biophysics and the mechanism of action of ionizing radiation June 21-24, 1960 K., 44-45.

28. Gorodetsky, A.A., Baraboy, V.A. (1963). Sodium gallate is a new means of prevention and treatment of acute radiation sickness. In the book: IV Congress of Radiologists and Radiologists of the Ukrainian SSR. Abstracts of reports. Kiev-Kharkov, 324.

29. Gorodetsky, A.A. (1954). Effect of phenamine on the course of radiation sickness. Abstracts of reports for scientific. session, dedicated. To the 30th anniversary of activity. V.M. Molotov Center. Research Institute rentgenol. and radiol. M., 16.
30. Gorodetskiy, A.A., Baraboy, V.A. (1961). Chemoprophylaxis and chemotherapy of experimental health problems. Physiological journal of the Academy of Sciences of the URSR, 5, 617-624.

31. Gorodetsky, O. A., Baraboy, V. A., Chernetsky, V. P. (1961). Zakhisna diya deyakykh ingibitoriv lantsyugovyh oxidative processes in case of hospitality exchange ailments. Dopovidi AN URSR, 6, 812-815.

32. Gorodetsky, A.A., Pelkis, P.S., Ryabova, E.Z., Dubenko, R.G. (1964). Antiradiation properties of arylamides and arylhydrazides of thiocarboxylic acids. K.,111.

33. Gorodetsky, A.A., Khomutovsky ,O.A., Ryabova, E.Z. (1960). Experimental prophylaxis and therapy of radiation sickness caused by external and internal radiation. In the book: Medical Radiology. Proceedings of the All-Union Conference on the Application of Radioactive and Stable Isotopes and Radiation in the National Economy and Science. April 4-12, 1957 M., 275281.

34. Komisarenko, V.P. (1960). Splenin, its biological and political power. Physiological journal, 5. 672-689.

35. Chebotarev, E.E. (1960). The use of splenin in experiment and clinic for radiation injuries. In the book: Materials of a scientific conference on biophysics and the mechanism of action of ionizing radiation June 21-24, 1960 K., 193-194.

36. Gorodetsky, A.A., Kirichinsky, B.R., Chebotarev, E.E. (1963). On the relative biological effect of neutron irradiation. In the book: IV Congress of Radiologists and Radiologists of the Ukrainian SSR. Abstracts of reports. Kiev-Kharkov. 262-263.

37. Gorodetsky, A.A., Kirichinsky, B.R., Chebotarev, E.E. (1969). On the relative biological efficiency of fast neutrons. In the book: Biological action of fast neutrons. Edited by A.A. Gorodetsky. K., Issue. 1, 3-13.

38. Vinogradova R.P., Danilova V.M. Laureates of the National Academy of Sciences of Ukraine imeni O.V. Palladin 1995-1996. Ukrainian Biochemistry Journal. 2014. No. 2. P.142-143.

39. Chebotarev, E.E. (1960). The course of acute radiation sickness in dogs. Physiological Journal, 5, 652658.

40. Chebotarev, E.E. (1961). Changes in serum protein fractions in dogs with acute radiation sickness. Physiological Journal of the USSR Academy of Sciences,1, 83-91.

41. Lipkan, N.F., Pindich, M.T. (1963). On the normalization of some metabolic processes in animals irradiated with X-rays and treated with a complex method. In the book: IV Congress of Radiologists and Radiologists of the Ukrainian SSR. Abstracts of reports. Kiev-Kharkov, 325.

42. Chebotarev E.E. (1963). Experimental experience of complex treatment of acute radiation sickness. In the same place. In the book: IV Congress of Radiologists and Radiologists of the Ukrainian SSR. Abstracts of reports. Kiev-Kharkov, 326-327.

43. Chebotarev, E.E., Ryabova, E.Z. (1970). Protective properties of homologous DNA when animals are irradiated with fast neutrons. In the book: The effect of 
ionizing radiation on proteins and nucleic acids. Molecular defense mechanisms. K., 238-242.

44. Boris Rajewsky. Electronic resource. Access mode: https://en.wikipedia.org/wiki/Boris_Rajewsky

45. Raevsky, B. (1959). Doses of radioactive radiation and their effect on the body. M., 205.
46. Guskova, A.K., Baysogolov, G.D. (1971). Human radiation sickness.M., 22.

47. Boychak, M.P. (2020). Draw from the history of the Ukrainian military therapy. Book 2. K., 216-221.

\section{ОСТРАЯ ЛУЧЕВАЯ БОЛЕЗНЬ: ВКЛАД УКРАИНСКИХ УЧЕНЫХ (сообщение первое)}

Институт физиологии имени А.А. Богомольца НАН Украины - лидер в изучении проблем острой лучевой болезни. научные школы А.А. Городецкого, Е.Е. Чеботарева.

Немецкий биофизик украинского происхождения Б.Н. Раевский и профессор Е.Б. Закржевский

\section{М.П. Бойчак}

Украинская военно-медицинская академия, г. Киев, Украина

Цель. Рассмотреть вклад украинских ученых в развитие представлений о биологическом действии ионизирующего излучения, патогенезе, клинике, диагностике, лечении и профилактике острой лучевой болезни.

Материалы и методы исследования. $B$ исследовании использованы исторический, библиосемантический методы с целью полного раскрытия вопросов становления и развития радиационной медицины, в частности, касающихся актуальных вопросов острой лучевой болезни.

Результаты исследования. Рассмотрены основные исследования украинских ученых Института физиологии имени А.А. Богомольца АН УССР и отдельных исследователей - украинцев по происхождению (Б.Н.Раевский и Е.Б. Закржевский) по вопросам медицинской радиологии, участия их в формировании современных представлений об острой лучевой болезни. Показана их роль в изучении вопросов патогенеза, клинического течения, лечения и профилактики острой лучевой болезни. Определены приоритетные направления достижений, оказавшие положительные результаты на лечение острой лучевой болезни у ликвидаторов аварии на Чернобыльской АЭС.

Выводы. Украинскими учеными Института физиологии имени А.А.Богомольца АН УССР и отдельными исследователями - украинцами по происхождению (Б.Н. Раевский, Е.Б. Закржевский) разработаны важные научные направления по изучению острой лучевой болезни (внесен определенный вклад в изучение патогенетических механизмов заболевания; подробно описано развернутую картину основных клинических синдромов; обосновано принцип комплексного, патогенетического лечения острой лучевой болезни; найдено, изучено и применено целый ряд эффективных противолучевых средств с разными механизмами действия, имеющими как радиозащитные свойства, так и снижающие степень лучевого повреждения организма), которые получили признание и практическое применение при лечении пострадавших во время аварии на Чернобыльской АЭС. Благодаря достижениям украинских ученых были сформулированы современные представления об острой лучевой болезни.

Ключевые слова: острая лучевая болезнь, радиобиология, медицинская радиология, ионизирующее излучение, рентгеновское излучение, рентгеновское облучение, гамма-облучение, нейтронное облучение,

\section{ACUTE RADIATION DISEASE: CONTRIBUTION OF UKRAINIAN SCIENTISTS} (notice one)

Institution of Physiology named after O.O.Bohomolets of the National Academy of Sciences of Ukraine is a research leader of the acute radiation sickness. scientific school by 0.O.Horodetskiy, E.E. Chebotarev.

German Biophysicist of Ukrainian origin B.M.Rayevskiy \& Professor E.B. Zakrzhevskiy

\section{M.P.Boichak}

\section{Ukrainian Military Medical Academy, Kyiv, Ukraine}

Purpose. Consider inputs of Ukrainian scientists onto development of understanding about the biological effects of ionizing radiation, pathogenesis, clinic, diagnostics, treatment and prevention of the Acute Radiation Sickness.

Materials and methods. It was used historical and bibliosemantic methods aimed at full disclosure of the formation and development of radiation medicine, in particular related to topical issues of the Acute Radiation Sickness.

Results. The main researches of Ukrainian scientists of the Institution of Physiology named after O.O.Bohomolets of the Academy of Sciences of Ukrainian SSR and some researches of Ukrainian origin (B.M.Rayevskiy 
and Ye.B.Zakrzhevskiy) on medical radiology, their participation in the formation of the current understanding of the Acute Radiation Sickness. Their roles in the studying of pathogenesis, clinical course, treatment and prevention of the Acute Radiation Sickness. The priority achievements have been identified that influenced onto the treatment of the Acute Radiation Sickness of Chernobyl accident consequences liquidators.

Conclusions. Ukrainian scientists of the Institution of Physiology named after O.O.Bohomolets of the Academy of Sciences of Ukrainian SSR and some researches of Ukrainian origin (B.M.Rayevskiy and Ye.B.Zakrzhevskiy) developed important scientific directions to further study the Acute Radiation Sickness as follows: made certain contribution in study of pathogenetic mechanisms of the decease; described the main picture of major clinical syndromes in details; substantiated the principle of complex (combined), pathogenetical treatment of the Acute Radiation Sickness; invented, researched and applied a number of efficient anti-radiation remedies, of various mechanics of action that have both radio-protective features and ability to decrease the degree of radiation damage. The above mentioned results have been recognized and used for treatment of the victims of the accident on the Chernobyl Nuclear Power Plant. The modern ideas about the Acute Radiation Sickness have been formed owing to the achievements by the Ukrainian scientists.

Key words: the Acute Radiation Sickness, radiobiology, medical radiology, ionizing radiation, X-ray irradiation, Gamma-irradiation, neutron irradiation, radiation-protectants.

\section{Відомості про автора:}

Бойчак М.П., - генерал-майор медичної служби у відставці, доктор медичних наук, професор, професор кафедри військової терапії Української військово-медичної академії, м. Київ, Україна.

\section{Сведения об авторе:}

Бойчак М.П., - генерал-майор медицинской службы в отставке, доктор медицинских наук, профессор, профессор кафедры военной терапии Украинской военно-медицинской академии, г. Киев, Украина.

Information about author:

Boichak M.P., - Major-general of MS, retired, DM DSc, Prof., Professor of military therapy department at Ukrainian Military-Medical Academy, Email: MPBoichak@ukr.net, https://orcid.org/0000-0002-8289-6239

Адреса для листування: вул. Московська, 45/1, буд. 33, м. Київ 01015 